\title{
Phenotypic and Genotypic Characterization of Uromyces appendiculatus from Phaseolus vulgaris in the Americas
}

C. M. Araya, A. T. Alleyne, and J. R. Steadman, Department of Plant Pathology, University of Nebraska - Lincoln, Lincoln, NE 68583-0722; K. M. Eskridge, Department of Biometry, University of Nebraska - Lincoln, Lincoln, NE 68583-0712; and D. P. Coyne, Department of Horticulture, University of Nebraska, Lincoln 68583-0724

\begin{abstract}
Araya, C. M., Alleyne, A. T., Steadman, J. R., Eskridge, K. M., and Coyne, D. P. 2004. Phenotypic and genotypic characterization of Uromyces appendiculatus from Phaseolus vulgaris in the Americas. Plant Dis. 88:830-836.

Populations of 90 Uromyces appendiculatus isolates were collected from throughout the Americas and evaluated for virulence on 19 standard bean rust differentials, and also on 12 landraces of Phaseolus vulgaris from South and Central America. The landrace differentials represented geographical centers of bean domestication. Three groups were observed. Two groups were isolates from centers of bean domestication and a third heterogeneous group comprised isolates from countries in South and Central America. Molecular analysis using random amplified polymorphic DNA-polymerase chain reaction (RAPD-PCR) was also conducted on these isolates. Cluster analysis of the molecular profiles showed three groups that corresponded to those obtained by virulence tests. These results show a clear differentiation of the pathogen population along similar lines as its host and suggest parallel evolution in the bean rust pathosystem.
\end{abstract}

Additional keyword: coevolution

Bean rust, caused by Uromyces appendiculatus (Pers.:Pers.) Unger, limits common bean (Phaseolus vulgaris L.) production globally. Common beans are among the most important grain legumes in the world and are the main source of dietary protein for small landholders in many developing countries. Common bean exhibits high variability for morphological (30), biochemical, and genetic (11) traits, and has been classified into six landraces (25). Two gene pools, Andean and Middle American, comprising the main centers of domestication of common bean, have been proposed on the basis of morphological and biochemical characteristics and the geographical distribution of wild forms $(6,10,25)$. Generally, Middle American forms comprise bean seeds that are small in size and less variable in seed coat color. In contrast, Andean types are larger seeded, have a

Corresponding author: J. R. Steadman

E-mail: jsteadman1@unl.edu

Present address of C. M. Araya: National University, School of Agricultural Sciences, Phytopathology Laboratory, Heredia 86-3000, Costa Rica.

Present address of A. T. Alleyne: Edward Waters College, Biological Sciences, 1658 Kings Road, Jacksonville, FL 32209.

D. P. Coyne is deceased.

Accepted for publication 29 March 2004.

Publication no. D-2004-0527-01R

(C) 2004 The American Phytopathological Society considerable range of seed coat color, and are more widely distributed globally as commercial cultivars (25). The present study sought to determine the pathogenic relationship of $U$. appendiculatus from the Americas, which includes the two main centers of domestication of common bean.

$U$. appendiculatus possesses many physiological races and is also highly variable in pathogenicity (19). Harter et al. (8) first detected two physiological races in 1935 , but by 1996 more than 300 races had been reported worldwide (2). These races have been used in breeding programs for identifying and enhancing rust resistance in bean germ plasm (21), although several races still cause major losses in Latin America and Africa (29). Several plant pathogens including the rusts have been shown to have an evolutionary relationship with their hosts, resulting from continuous adaptation to changes in host morphology, biochemistry, and ecology $(1,17)$. This allows individual components in the pathosystem to coexist in a dynamic equilibrium with each other (22). Virulent pathotypes of another bean pathogen, Phaeoisariopsis griseola (Sacc.) Ferraris, show that its distribution mirrors the Andean and Middle American gene pools of common bean $(7,20)$. Recent studies also indicate that point mutations in virulence genes give rise to regional differences, such as the Afro-Andean group in $P$. griseola (15). Similar results have also been reported for pathotypes of the bean anthracnose pathogen Colletotrichum lindemuthianum (Sacc. \& Magnus) Lams.-Scrib. $(18,21)$.
Sandlin et al. (24) described two primary random amplified polymorphic DNA (RAPD) banding patterns and a third intermediate fingerprint pattern, comprising a mixture of these two main types using DNA from five pairs of rust $U$. appendiculatus pathotypes. The banding patterns or DNA fingerprints of these pathotypes represented the two major bean host gene pools and an intermediate group comprised of pathotypes from both. Similarly, a study of Australian isolates of $U$. appendiculatus using RAPD fingerprints also showed a group of isolates with an intermediate molecular profile characteristic of the two major gene pools $(3,14)$. However, neither of these studies used an extensive collection of isolates collected from fields in the main growing regions of bean domestication. In the current study, pathogenic variability was determined by virulence tests on a large population of isolates from South and Central America, and RAPD analysis was used to determine molecular relationships between $U$. appendiculatus isolates and the host phenotypes. The objectives of this study were to determine if an intermediate group of pathotypes from both host gene pools was also evident in this large population and to provide a better understanding of virulence diversity that will facilitate resistance gene deployment in the Americas.

\section{MATERIALS AND METHODS}

Field collections of $U$. appendiculatus were obtained from beans grown in Argentina, Brazil, Bolivia, Ecuador, and Peru representing the gene pool of Andean isolates, and from beans grown in Costa Rica, Cuba, Dominican Republic, El Salvador, Guatemala, Honduras, Jamaica, and Mexico representing the gene pool of Middle American isolates (Table 1). In each field, uredinia were collected from leaves of beans in commercial, experimental, or small landholdings. The gene pool of each isolate was assigned based on the country or area of collection, rather than on the gene pool of the bean host from which the isolate was obtained.

Virulence tests. The 90 single uredinium isolates (SUIs) shown in Table 1 were inoculated in triplicate on the standard set of differentials according to described procedures (28). A suspension of $8 \times 10^{-2} \mathrm{mg} \mathrm{ml}^{-1}$ fresh urediniospores in $4 \%$ Tween 20 solution was inoculated onto primary leaves (35 
to $65 \%$ expanded). The plants were allowed to dry and then incubated in a mist chamber for $16 \mathrm{~h}$ at $21 \pm 1^{\circ} \mathrm{C}$. After misting, plants were moved to a growth chamber at $22^{\circ} \mathrm{C}$, light intensity $117 \mu \mathrm{E} \mathrm{m}^{-2} \mathrm{~s}^{-1}$, and 14-h day length. Disease reactions were recorded 14 days after inoculation using the quantitative rust disease rating scale shown in Table 2 (19). Reactions 1.1 to 3.1 were considered resistant or $\mathrm{R}$ reactions, and 3.2 to 6.1 were susceptible or $\mathrm{S}$ reactions. Inoculation and evaluation on the standard differentials were repeated twice for all isolates.

A second set of differentials made up of six Andean and six Middle American bean landraces was also used to determine the specificity of SUIs from both centers of domestication. The landraces were chosen from an original group of 306 landraces used by Singh et al. (25) to characterize the gene pools of domesticated P. vulgaris. Separate inoculations of each SUI were made twice on the six Andean and six Middle American landrace differential set following the same procedure and conditions described above for the standard differential set.

DNA extraction. The procedure for DNA extraction was based on the method described by Linde et al. (13). Urediniospores $(50 \mathrm{mg})$ were germinated in petri dishes in a $0.01 \mathrm{M}$ phosphate buffer, $\mathrm{pH}$ $7.0 \quad(6.0 \mu \mathrm{M}$ calcium phosphate, $0.5 \%$ ethanol, $0.01 \%$ Tween $20,5 \% \beta$-ionone, and $10.0 \mu \mathrm{M}$ rifampicin) and kept at $21^{\circ} \mathrm{C}$ for $8 \mathrm{~h}$. Germinated spores were frozen and then ground in liquid nitrogen. The

Table 1. List of 90 single uredinium isolates of Uromyces appendiculatus evaluated on 19 standard and 12 landrace bean rust differentials and by random amplified polymorphic DNApolymerase chain reaction (RAPD-PCR) molecular markers

\begin{tabular}{lll}
\hline $\begin{array}{l}\text { No. of } \\
\text { isolates }\end{array}$ & $\begin{array}{l}\text { Country of } \\
\text { isolation }\end{array}$ & \multicolumn{1}{c}{$\begin{array}{c}\text { Isolate } \\
\text { gene pool }\end{array}$} \\
\hline $1-8$ & Argentina & Andean \\
$11-13$ & Argentina & Andean \\
$15-18$ & Argentina & Andean \\
$19-27$ & Bolivia & Andean \\
$28-31$ & Brazil & Andean \\
$32-34$ & Ecuador & Andean \\
$36-38$ & Ecuador & Andean \\
42 & Ecuador & Andean \\
$43-48$ & Peru & Andean \\
$50-53$ & Costa Rica & Middle American \\
$54-58$ & Cuba & Middle American \\
$59-60$ & Dominican Rep. & Middle American \\
$62-72$ & Dominican Rep. & Middle American \\
$74-79$ & El Salvador & Middle American \\
80 & Guatemala & Middle American \\
$81-83$ & Honduras & Middle American \\
$84-89$ & Honduras & Middle American \\
92 & Honduras & Middle American \\
$94-95$ & Honduras & Middle American \\
97 & Honduras & Middle American \\
100 & Honduras & Middle American \\
101 & Jamaica & Middle American \\
$103-107$ & Mexico & Middle American \\
\hline
\end{tabular}

a Collection number for this study. powder was incubated $1 \mathrm{~h}$ at $65^{\circ} \mathrm{C}$ in 600 $\mu \mathrm{l}$ of extraction buffer $(600 \mathrm{mM}$ potassium ethyl xanthogenate, $1.4 \mathrm{M} \mathrm{NaCl}, 200 \mathrm{mM}$ Tris-HCL, $\mathrm{pH} 7.5$, and $20 \mathrm{mM}$ EDTA). After incubation, each sample was centrifuged for $10 \mathrm{~min}$ at $16,000 \times g$, and the supernatant was precipitated with a $6: 1$ mixture of ethanol and $7 \mathrm{M}$ ammonium acetate at $-20^{\circ} \mathrm{C}$. After centrifugation for $30 \mathrm{~s}$, the pellet was washed with $70 \%$ ethanol and rehydrated in $200 \mu \mathrm{l}$ of TE buffer ( $1 \mathrm{mM}$ Tris, $0.1 \mathrm{mM}$ EDTA). RNA was removed by adding $200 \mathrm{ng}$ of RNase A to the suspension, which was incubated $1 \mathrm{~h}$ at $37^{\circ} \mathrm{C}$. DNA was precipitated at $-20^{\circ} \mathrm{C}$ by adding $500 \mu \mathrm{l}$ of a mixture of ethanol and 3 M sodium acetate (20:1 $\mathrm{vol} / \mathrm{vol}$ ) to the suspension. The final DNA

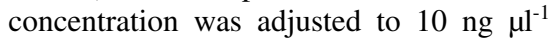
TE buffer.

Polymerase chain reactions. The polymerase chain reaction (PCR) was performed in a $1600 \mathrm{X}$ air-thermocycler (Idaho Technologies Inc., Madison, WI) as described by Skroch and Nienhuis (26). Flame sealed $20-\mu \mathrm{l}$ capillary glass tubes were loaded with a mixture of $2 \mu$ of DNA of each isolate plus $8 \mu \mathrm{l}$ of a master mix (0.1 mM DNTP, 0.5 unit Taq, $0.4 \mu \mathrm{M}$ primer, $1 \times$ reaction buffer, $2 \mathrm{mM} \mathrm{MgCl}_{2}$, $50 \mathrm{mM}$ Tris, $\mathrm{pH} 8.5,20 \mathrm{mM} \mathrm{KCl}$, and 2 $\mu \mathrm{M}$ bovine serum albumen). DNA amplification was set at two cycles of $60 \mathrm{~s}$ at $91^{\circ} \mathrm{C}, 7 \mathrm{~s}$ at $42^{\circ} \mathrm{C}$, and $70 \mathrm{~s}$ at $72^{\circ} \mathrm{C}$, and 38 cycles of $1 \mathrm{~s}$ at $91^{\circ} \mathrm{C}, 7 \mathrm{~s}$ at $42^{\circ} \mathrm{C}$, and $70 \mathrm{~s}$ at $72^{\circ} \mathrm{C}$. After amplification, samples were loaded directly onto a $1.5 \%$ agarose gel, and electrophoresis was conducted at 116 to $120 \mathrm{mV}$ for $2 \mathrm{~h}$. The gel was stained for 20 min with ethidium bromide $\left(0.5 \mu \mathrm{g} \mathrm{ml}^{-1}\right)$ and then destained for $10 \mathrm{~min}$ in deionized water. Thirteen 10-base-pair random primers (Operon Technologies. Alameda, CA) shown to give a large number of polymorphisms were used. These included OPA01-CAGGCCCTTC, OPA07-GAAAC GGGTG, OPA10-GTGATCGCAG, OPA11CAATCGCCGT, OPA17-GACCGCTTGT, OPA18-AGGTGACCGT, OPB11-GTAGA CCCGT, OPB13-CAGCACCCAC, OPF03CCTGATCACC, OPF04-GGTGATCAGG, OPF05-CCGAATTCCC, OPF15-CCAGT ACTCC, and OPF16-GGAGTACTGG. DNA extraction and subsequent PCR analysis were repeated once and carried out in duplicate reactions.

Data analysis. The virulence reactions of both standard and landrace differentials were recorded as quantitative disease scores for each differential based on the rust resistance scale (19). When two uredinia sizes were detected on the same leaf, the score was determined by using the greatest frequency in size of each uredinium (Table 2). Virulence patterns for each isolate were scored using a binary system based on the frequency of R (1 to 3.2) and S (3.3 to 6.0)

Table 2. Reaction types adopted in virulence survey of bean pathogen (Uromyces appendiculatus) populations and their corresponding quantitative disease score

\begin{tabular}{llcc}
\hline $\begin{array}{l}\text { Reaction } \\
\text { type }\end{array}$ & Description & $\begin{array}{c}\text { Quantitative } \\
\text { disease score }^{\mathbf{a}}\end{array}$ & $\begin{array}{c}\text { Rust } \\
\text { reaction }^{\text {Isean }}\end{array}$ \\
\hline 1 & Immune, no visible symptoms & 1.0 & $\mathrm{R}$ \\
2 & Necrotic or chlorotic spots without sporulation & 2.1 & $\mathrm{R}$ \\
3 & Uredinia $\leq 300 \mu$ m in diameter & 3.1 & $\mathrm{R}$ \\
4 & Uredinia $301-500 \mu$ m in diameter & 4.1 & $\mathrm{~S}$ \\
5 & Uredinia $501-800 \mu$ m in diameter & 5.1 & $\mathrm{~S}$ \\
6 & Uredinia $801-1,200 \mu$ m in diameter & 6.1 & $\mathrm{~S}$ \\
\hline
\end{tabular}

${ }^{a}$ Mmbaga et al. (19).

Table 3. Comparison of means of average disease score of Uromyces appendiculatus from Latin America and the Caribbean on two sets of bean landrace differentials

\begin{tabular}{lllcc}
\hline & & \multicolumn{2}{c}{ Mean of disease score and standard deviation } \\
\cline { 3 - 5 } $\begin{array}{l}\text { Differential } \\
\text { code }^{\mathbf{a}}\end{array}$ & Landrace differential & $\begin{array}{c}\text { Andean } \\
\text { isolates }^{\mathbf{b}}\end{array}$ & $\begin{array}{c}\text { Middle American } \\
\text { isolates }^{\mathbf{c}}\end{array}$ & $\begin{array}{c}\text { Total } \\
\text { population }^{\mathbf{d}}\end{array}$ \\
\hline A-1 & Jatu Rong & $4.5 \pm 1.2$ & $4.7 \pm 0.9$ & $4.6 \pm 1.0$ \\
A-2 & Jalo EEP 558 & $2.4 \pm 1.1$ & $3.6 \pm 1.8$ & $3.1 \pm 1.6$ \\
A-3 & Tórtolas Corrientes & $1.9 \pm 1.3$ & $3.3 \pm 1.8$ & $2.7 \pm 1.7$ \\
A-4 & Blanc Español & $2.5 \pm 1.7$ & $4.4 \pm 1.4$ & $3.5 \pm 1.8$ \\
A-5 & Bolón Rojo & $1.6 \pm 1.2$ & $2.7 \pm 1.8$ & $2.1 \pm 1.7$ \\
A-6 & Bolón Bayo & $4.0 \pm 1.8$ & $3.4 \pm 1.7$ & $3.6 \pm 1.8$ \\
M-1 & Carioca & $5.3 \pm 0.3$ & $5.1 \pm 0.3$ & $5.1 \pm 0.3$ \\
M-2 & Rio Tibagi & $5.5 \pm 0.4$ & $5.1 \pm 0.4$ & $5.3 \pm 0.5$ \\
M-3 & Zacatecano & $5.2 \pm 0.6$ & $3.7 \pm 1.6$ & $4.4 \pm 1.5$ \\
M-4 & Guanajuato 31 & $3.3 \pm 1.2$ & $3.6 \pm 1.2$ & $3.4 \pm 1.3$ \\
M-5 & Flor de Mayo & $5.0 \pm 0.3$ & $4.4 \pm 0.8$ & $4.7 \pm 0.7$ \\
M-6 & Amarillo 154 & $5.1 \pm 1.2$ & $4.4 \pm 1.2$ & $4.5 \pm 1.2$ \\
\hline
\end{tabular}

a A-1 to A-6 are Andean landrace differentials and M-1 to M-6 are Middle American landrace differentials.

${ }^{\mathrm{b}} \mathrm{N}=41$ Andean isolates.

${ }^{\mathrm{c}} \mathrm{N}=49$ Middle American isolates.

${ }^{\mathrm{d}} \mathrm{N}=90$ isolates. 
reactions in the standard or landrace differential sets. The means and standard deviation of each disease score on the 12 landrace differentials of the 90 SUIs were computed using SAS pc ver. 8.0. (SAS Institute, Cary, NC). Hierarchical cluster analysis and the unweighted pair group method average (UPGMA) procedure (27) were based on Euclidean distance analysis in NTSYS version 2.0 (23). Two dendrograms, one each for the standard and landrace differentials, were prepared for the 90 SUIs used.

Hierarchical cluster analysis was also performed on the 90 SUIs using 50 polymorphic RAPD DNA bands and the UPGMA procedure. Cluster analysis for the RAPD bands was based on the simple matching coefficient (SM) in NTSYS. RAPD and virulence data matrices were compared by transforming all data matrices using the SMC analysis in NTSYS and computing a matrix correlation coefficient, $r$, using matrix comparison (MXCOMP) analysis in NTSYS and tables of critical $r$ values for comparison of independent phylogenetic trees (12).

\section{RESULTS}

Virulence reaction. A total of 206 different virulence patterns were detected based on the rust reaction of both the 19 standard and 12 landrace differentials for 90 isolates of $U$. appendiculatus. Ninetyfour virulence patterns were found on the standard differentials, 46 on the Andean landrace differentials and 66 on the Middle American landrace differentials. The mean virulence recorded as disease scores on Middle American landrace differentials was higher than on Andean landrace differentials (Table 3). Generally, isolates from countries in Middle America such as Honduras and Mexico were more virulent than those from the Andean areas such as Ecuador and Bolivia. However, individual Andean isolates had higher disease scores on Middle American landrace differentials than some Middle American isolates, while most Middle American isolates showed consistently high to medium disease scores on both Andean and Middle American landrace differentials.

RAPD-PCR and cluster analyses. Fifty scorable polymorphic bands of amplified DNA fragments were generated by the 13 random PCR primers. Markers ranged from 470 to 1,600 base pairs. RAPD profiles showed a more uniform pattern for isolates from countries in the Andean region and a more variable pattern for $U$. appendiculatus isolates from the Middle American region. Andean and Middle American isolates were separated by the absence of two RAPD markers $\left(\mathrm{OA} 11_{600}\right.$ and OA11 ${ }_{650}$ ) in Middle American isolates, while OF15, 1,000 was present in most of the Andean pathotypes but absent in all those of Middle American origin.
Cluster analysis of the disease scores on both the standard and landrace differential sets showed three main clusters of isolates over $60 \%$ of the genetic distance (Figs. 1 and 2). Isolates were separated into geographic groups based on the predominance of Andean or Middle American isolates found in that particular group. The Andean group (AI) contained a nearly homogenous number of Andean isolates while the Middle American group (MI) contained Middle American isolates alone. If Andean or Middle American isolates were not the dominant isolates in either of these two groups, the group was designated a heterogeneous or mixed group (AI-MI).

Cluster analysis of RAPD banding patterns of the 90 SUIs also showed three main clusters containing either predominantly Middle American or Andean isolates, and isolates from both regions at $60 \%$ similarity (Fig. 3). Many isolates $(84 \%)$ were found in the same group each time when the three categories based on RAPD and virulence data on both standard and landrace differentials were compared. Moreover, comparison of both molecular and virulence data matrices had significant correlations of $r=0.4$ and $r=0.3(P<$ $0.05)$, which showed that both the differential and landrace cluster analysis were associated with that of the RAPDs (Table 4).

\section{DISCUSSION}

The large number of virulence patterns from $90 U$. appendiculatus isolates on the 19 standard differentials provides evidence of the wide pathogenic diversity of this pathogen. These results confirm previous reports on $U$. appendiculatus variability in other populations and indicate that sexual recombination, heterokaryosis, mutation, gene flow, and environmental factors may be acting simultaneously on bean rust pathogen populations worldwide. U. appendiculatus isolates also showed differential pathogenicity to bean landraces from different gene pools. This phenomenon was previously observed by Sandlin et al. (24) using a narrow range of 10 selected pathotypes. In the present study, however, the isolates have a wider geographic origin and more diverse virulence. While Andean and Middle American isolates were virulent on landraces from either gene pool, more individual Andean isolates displayed greater regional or geographic specificity than Middle American isolates. In countries such as Honduras where the Middle America bean gene pool is represented, wild, weedy, and landrace forms of common bean and other Phaseolus spp. are found growing in close proximity to commercial varieties. This proximity and opportunity for urediniospore exchange and basidiospore formation may be responsible for the high virulence and greater variability seen in Middle America pathogen populations compared with those in temperate or Andean regions where commer- cial production is not within 200 or more kilometers of wild beans or in Andean regions where commercial production is at lower altitudes in comparison with higher altitudes for wild, weedy beans. Therefore, a better understanding of the genetic basis of $U$. appendiculatus virulence diversity in this region will facilitate the search for new sources of resistance and lead to beneficial disease management strategies by increasing the number of rust resistance genes currently available for deployment in these countries.

Three groups of $U$. appendiculatus isolates from the Americas were confirmed in this study by using both phenotype (virulence) and genotype (RAPD) analysis. The use of both the standard set of 19 differentials, which consists of more Middle American than Andean sources of resistance, and the unique set of 12 landrace differentials without bias to resistance to rust but with an equal number of both Andean and Middle American host lines/ cultivars both showed the same three cluster groups among most of the isolates used in this study. These groups include isolates from the two major bean gene pools and a pre-ancestral or an intermediate group, initially suggested by Gepts and Bliss (5) based on phaseolin seed protein, in common bean from the centers of bean domestication. There are similar reports for host coevolution for pathogens such as Magnaporthe poae (9), Erysiphe graminis $\mathrm{f}$. sp. hordei (16), Fusarium oxysporum f. sp. cucurbitae (4), C. lindemuthianum $(18,20)$, and $P$. griseola (20). Previous reports of a mixed virulence group of $U$. appendiculatus $(3,14,24)$ pathotypes, which we also reported here, may provide further evidence of a transition area between these two gene pools in both the common bean host and bean rust pathogen isolates. It is therefore probable that ongoing adaptation between pathogen and host is responsible for the characterization of these major groups.

Management of bean rust is most efficacious if producers employ a combination of resistant cultivars, cultural practices such as removal of bean debris and volunteer beans, and fungicides. The wide and differential virulence displayed by isolates from the Americas to both the Andean and Middle American gene pools of common bean has two implications for release of resistant bean cultivars. Cultivars with single resistance genes should not be used, and resistance genes from both gene pools should be deployed where genes are pyramided for more durable resistance to rust (21). In addition, the large number of virulence patterns in isolates from the Americas, some of which were unique to certain countries (data not shown), require use of specific resistance genes in different regions.

Although this study shows a clear differentiation among $U$. appendiculatus 


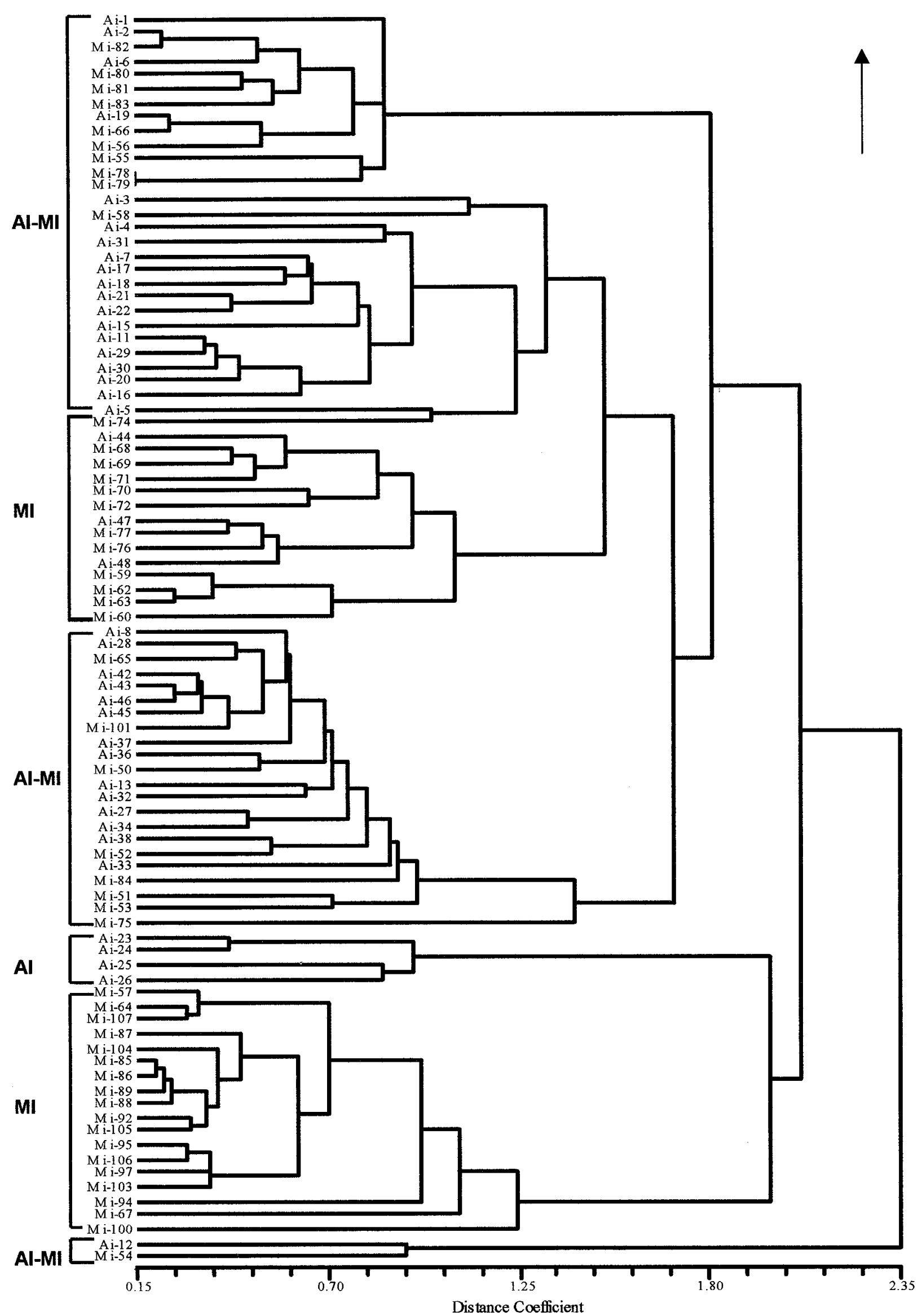

Fig. 1. Dendrogram showing three main groups (Middle American group or MI, Andean group or AI, and the Andean-Middle American group or AI-MI) of 90 Uromyces appendiculatus isolates using the unweighted pair group method average (UPGMA) based on the disease reaction of the 19 standard bean rust differentials. 


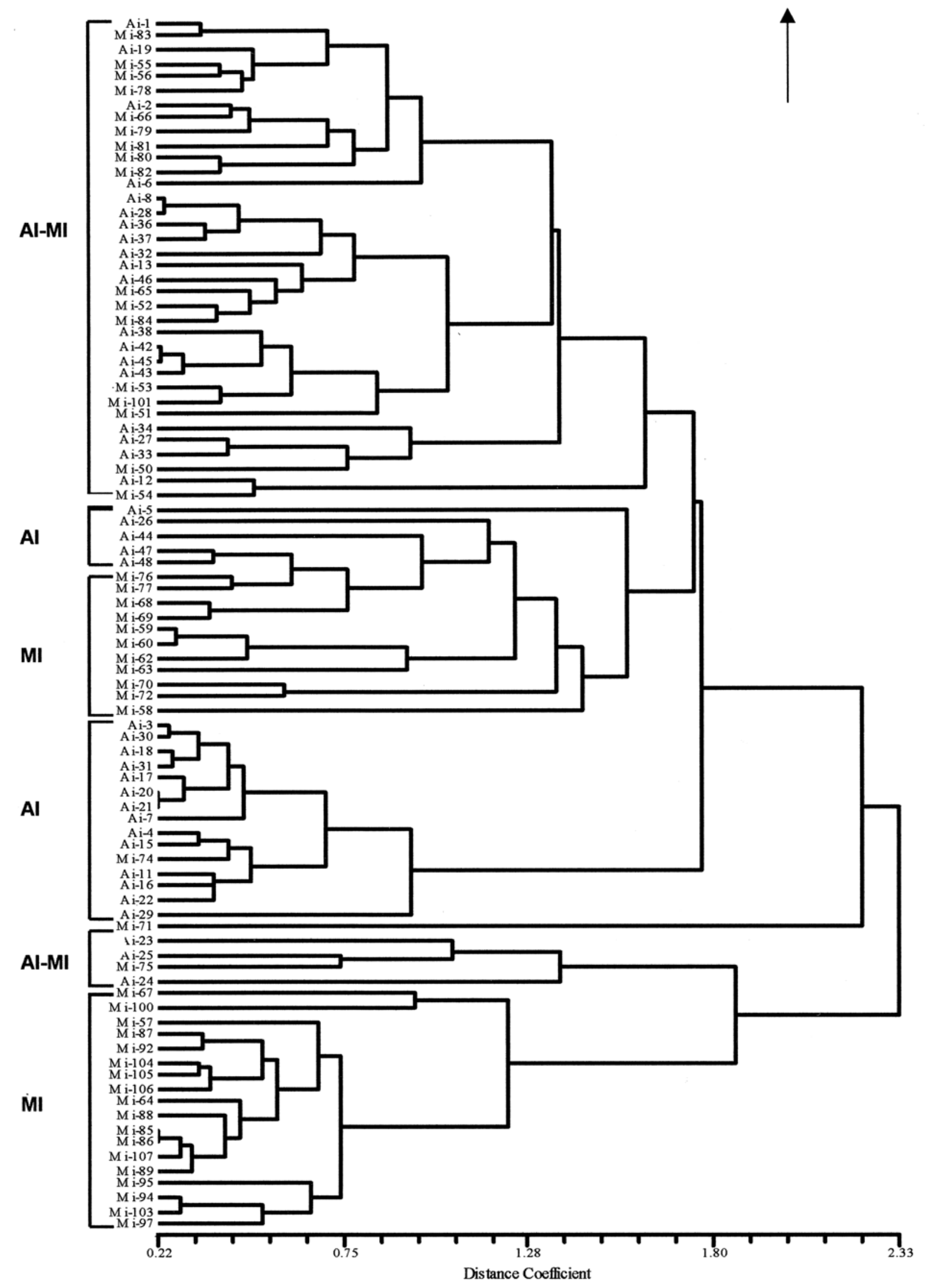

Fig. 2. Dendrogram showing three main groups (Middle American group or MI, Andean group or AI, and the Andean-Middle American group or AI-MI) of 90 Uromyces appendiculatus isolates using the unweighted pair group method average (UPGMA) based on the disease reaction of landrace bean differentials. 


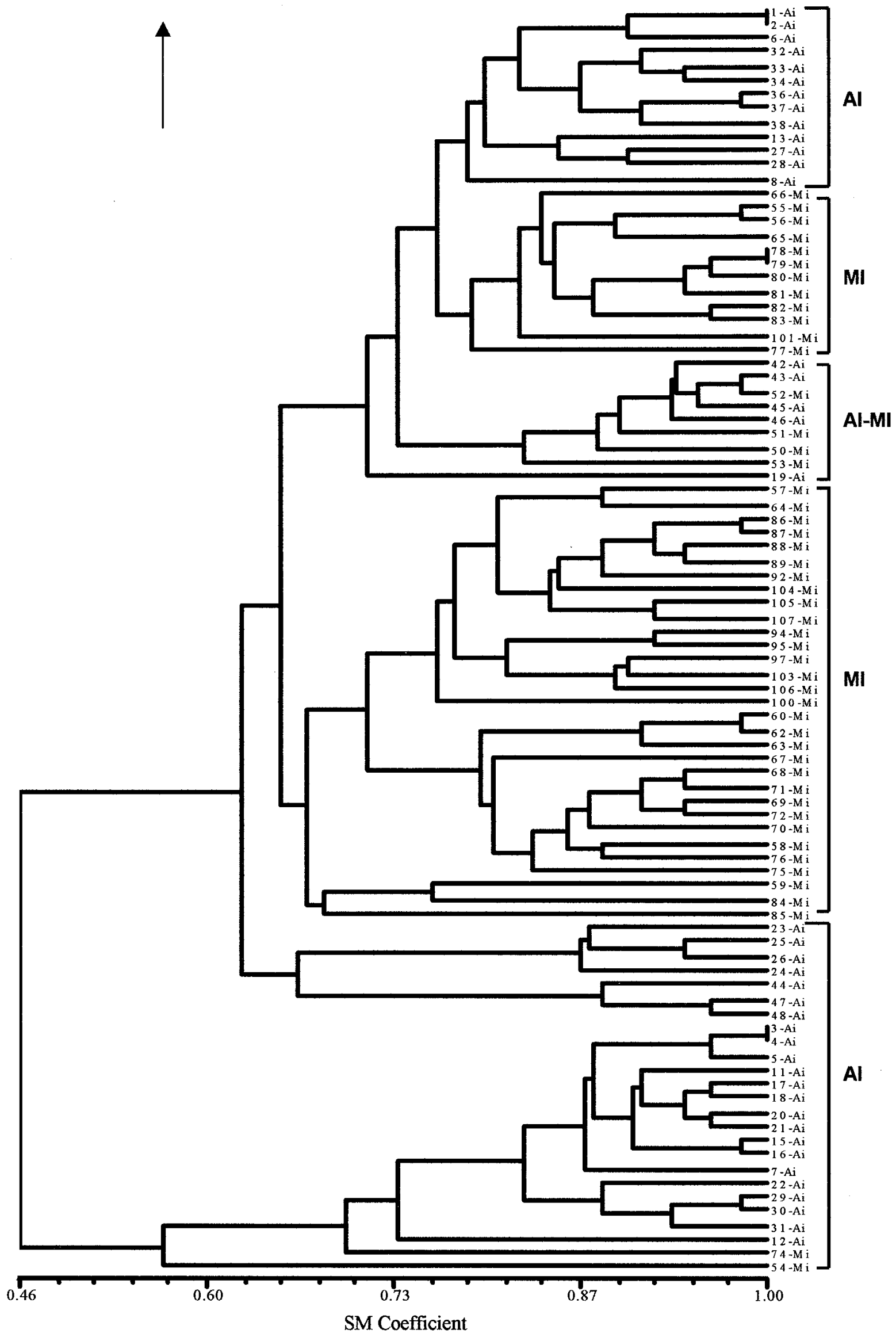

Fig. 3. Dendrogram showing three main groups (Middle American group or MI, Andean group or AI, and the Andean-Middle American group or AI-MI) of 90 Uromyces appendiculatus isolates using the unweighted pair group method average (UPGMA) based on 50 polymorphic random amplified polymorphic DNA (RAPD) bands. 
Table 4. Matrix comparison values $(r)^{\text {a }}$ for Andean and Middle American isolates based on virulence on standard and landrace differentials and random amplified polymorphic DNA (RAPD) markers

\begin{tabular}{lccc}
\hline & Standard differentials & Landrace differential & RAPD markers \\
\hline Standard differentials & 1.00 & 0.35 & 0.30 \\
Landrace differential & 0.35 & 1.00 & 0.42 \\
RAPD markers & 0.30 & 0.42 & 1.00 \\
\hline
\end{tabular}

${ }^{a}$ At $P \leq 0.05, \mathrm{~N}=90$, and $r=0.031$.

isolates that mirrors host bean gene pool classification, further analysis of pathogen and host interaction in the centers of bean domestication may require repeated sampling of these populations over several years. Phenotypic and molecular markers are also necessary to resolve the origin and geographic dissemination of the intermediate group found in this pathogen population. As such, for the past 3 years, annual collections of bean rust from wild and domesticated landraces from Honduras have been made and will be characterized using rep-PCR molecular markers associated with virulence to the race specific virulence gene $U r-6$ (James Steadman, personal communication). While the existence of the intermediate group makes disease management more challenging, further studies on these representative isolates should yield a greater understanding of the evolving patterns of disease epidemics both in this region and globally. In conclusion, bean rust management in the Americas and the Caribbean would benefit from further study of the hostpathogen relationships in countries where the pathogen population has not been widely sampled and characterized using these techniques.

\section{ACKNOWLEDGMENTS}

A contribution of the University of Nebraska Agricultural Research Division, Lincoln, NE. Journal Series No. 13650. We would like to thank Daniela O'Keefe and Geunhwa Jung for their help with this work and for the support of the Bean/Cowpea CRSP (USAID contract No. DAN1310-G-SS-6008-00).

\section{LITERATURE CITED}

1. Anikster, R. Y., and Wahl, I. 1979. Coevolution of the rust fungi on gramineae and liliaceas and their hosts. Annu. Rev. Phytopathol. 17:367-403.

2. Araya, C. M. 1996. Pathogenic and molecular variability and telia production of $U$. appendiculatus isolates from the Andean and Middle American centers of domestication of bean. Ph.D. diss. University of Nebraska, Lincoln.

3. Braithwaite, K. S., Manners, J. M., Erwin, J. A. G., and Maclean, D. J. 1994. DNA markers reveal hybrids between two diverse background genotypes in Australian collections of the bean rust fungus Uromyces appendiculatus. Aust. J. Bot. 42:255-267.

4. Crownhurst, R. N., Hawthorne, B. T., Rikkering, E. H. A., and Templeton, M. D. 1991. Differentiation of Fusarium solani f. sp. cucurbitae races 1 and 2 by random amplification of polymorphic DNA. Curr. Genet. 20:391-396.

5. Gepts, P., and Bliss, F. A. 1986. Phaseolin variability among wild and cultivated common beans (Phaseolus vulgaris) from Colombia. Econ. Bot. 40:469-478.

6. Gepts, P., and Debouck, D. 1991. Origin, domestication, and evolution of the common bean (Phaseolus vulgaris L.). Pages 7-53 in: Common Beans: Research for Crop Improvement. A van Schoonhoven and O. Voysest, eds. CIAT, Cali, Colombia.

7. Guzmán, P., Gilbertson, R. L., Nodari, R., Johnson, W. C., Temple, S. R., Mandala, D., Mkandawire, A. B. C., and Gepts, P. 1995. Characterization of variability in the fungus Phaeoisariopsis griseola suggests coevolution with the common bean (Phaseolus vulgaris). Phytopathology 85:600-607.

8. Harter, L. L., Andrus, C. F., and Zaumeyer, W. J. 1935. Studies on bean rust caused by Uromyces phaseoli typica on bean. J. Agric. Res. 50:737-759.

9. Huff, D. R., Bunting, T. E., and Plumley, K. A. 1994. Use of random amplified polymorphic DNA markers for the detection of genetic variation in Magnaporthe poae. Phytopathology $84: 1312-1316$.

10. Johnson, W. C., and Gepts, P. 2002. The role of epistasis in controlling seed yield and other agronomic traits in an Andean $\times$ Mesoamerican cross of common bean (Phaseolus vulgaris L.) Euphytica 125:69-79.

11. Khairallah, H. M., Adams, M. W., and Sears, B. B. 1990. Mitochondrial DNA polymorphism of Malawian bean lines: Further evidence for two major gene pools. Theor. Appl. Genet. 80:753-761.

12. Lapointe, F.-J., and Legendre, P. 1992. Statistical significance of the matric correlation coefficient for comparing independent phylogenetic trees. Systematic Biol. 41(3):378-384.

13. Linde, D. C., Groth, J. V., and Roelfs, A. P. 1990. Comparison of isozyme and virulence diversity patterns in the bean rust fungus Uromyces appendiculatus. Phytopathology 80:141-147.

14. Maclean, D. J., Braithwaite, K. S., Irwin, J. A. G., Manners, J. M., and Groth, J. V. 1995. Random amplified polymorphic DNA reveals relationships among diverse genotypes in Aus- tralian and American collections of Uromyces appendiculatus. Phytopathology 85:757-765.

15. Mahuku, G. S., Henriquez, M. A., Munoz, J., and Buruchara, R. A. 2002. Molecular markers dispute the existence of the Afro-Andean group of the bean angular leaf spot pathogen, Phaeoisariopsis griseola. Phytopathology 92:580-589.

16. McDermott, J. M., Brändle, U., Dutly, F., Haemmerli, U. A., Kellers, S., Müller, K. E., and Wolfe, M. S. 1994. Genetic variation in powdery mildew of barley: Development of RAPD, SCAR, and VNTR markers. Phytopathology 84:1316-1321.

17. McDonald, B. A., McDermott, J. M., Goodwing, S. B., and Allard, R. W. 1989. The population biology of the host-pathogen interactions. Annu. Rev. Phytopathol. 27:77-94.

18. Melotto, M., and Kelly, J. D. 2000. An allelic series at the $\mathrm{Co}-1$ locus conditioning resistance to anthracnose in common bean of Andean origin. Euphytica 116:143-149.

19. Mmbaga, M. T., Steadman, J. R., and Eskridge, K. M. 1996. Virulence patterns of Uromyces appendiculatus from different geographical areas and implications for finding durable resistance to rust in common bean. $\mathrm{J}$. Phytopathol. 144:533-541.

20. Pastor-Corrales, M. A. 1996. Traditional and molecular confirmation of the co-evolution of beans and pathogens in Latin America. Annu. Rep. Bean Improv. Coop. 39:46-47.

21. Pastor-Corrales, M. A., and Stavely, J. R. 2002. Using races of the common bean rust pathogen to detect resistance genes in Phaseolus vulgaris. Bean Improv. Corporative (BIC) Rep. 45:78-79.

22. Robinson, R. A. 1976. Plant pathosystems. Spring-Verlag, New York.

23. Rohlf, F. J. 1989. NTSYSpc Numerical taxonomy and multivariate analysis system. Exeter Publishing Co., Ltd., Setauket, NY.

24. Sandlin, C. M., Steadman, J. R., Araya, C. M. and Coyne, D. P. 1999. Isolates of Uromyces appendiculatus with specific virulence to landraces of Phaseolus vulgaris of Andean origin. Plant Dis. 83:108-113.

25. Singh, S. S., Gepts, P., and Debouck, D. 1991. Races of common bean (Phaseolus vulgaris, Fabaceae). Econ. Bot. 45:379-396.

26. Skroch, P., and Nienhuis, J. 1995. Impact of scoring error and reproducibility of RAPD data on RAPD based estimates of genetic distance. Theor. Appl. Genet. 91:1086-1091.

27. Sneath, P. H. A., and Sokal, R. R. 1973. Numerical Taxonomy. Freeman, San Francisco.

28. Stavely, J. R., Freytag, G. F., Steadman, J. R., and Schwartz, H. F. 1983. The 1983 bean rust workshop. Annu. Rep. Bean Improv. Coop. 26:4-6.

29. Stavely, J. R., and Pastor-Corrales, M. A. 1989. Rust. Pages 159-194 in: Bean Production Problems in the Tropics. H. F. Schwartz and M. A. Pastor-Corrales, eds. CIAT, Cali, Colombia.

30. Voysest, O., and Dessert, M. 1991. Bean cultivars: Classes and commercial seed types. Pages 119-162 in: Common Beans; Research for Crop Improvement. A. van Schoonhoven and O. Voysest, eds. CIAT, Cali, Colombia. 